\title{
How Socio-Economic Differences between Farmers Affect Forest Degradation in Western Mexico
}

\author{
Armonia Borrego * and Margaret Skutsch \\ Centro de Investigaciones en Geografía Ambiental, Universidad Nacional Autónoma de México, \\ Morelia CP 58190, Mexico; mskutsch@ciga.unam.mx \\ * Correspondence: armoniab@gmail.com; Tel.: +52-443-322-3865
}

Received: 23 August 2019; Accepted: 3 October 2019; Published: 9 October 2019

\begin{abstract}
Many forests under community use in tropical countries become degraded and lose carbon stocks as a result of agricultural activities such as shifting cultivation and cattle grazing, although these processes rarely result in deforestation. A better understanding of processes specifically causing forest degradation may be of interest to policy makers concerned with the design of programs to conserve forests, for example under international policy on Reducing Emissions from Deforestation and Forest Degradation (REDD+). On the basis of data from a farmer survey carried out in the western Pacific area of Mexico, this study uses a cross-sectional regression model to identify the variables that explain variations between groups of farmers in the amounts of land temporarily cleared for shifting cultivation, which results in decreasing the density of forest biomass. We found that, contrary to common perception about shifting cultivation, within each community, many farmers, both richer and poorer, carry out shifting cultivation. Moreover, it is the wealthier farmers that are making more temporary clearances for such activities when compared with those with less resources. We conclude that, for effectiveness in the design of national programs for REDD+, intra-community differences in farmer status should be taken into account. Moreover, REDD+ interventions should consider the impacts of this program on farmers without rights to land.
\end{abstract}

Keywords: forest degradation; farmers' choices; REDD+; rural communities

\section{Introduction}

In many regions around the world, services and products of forests play an important role in the maintenance of the livelihoods of households living in the local communities and may be an important component in communities' economic development [1-4]. However, the use of forest land and products has often resulted in decline of forest stock, both through deforestation (land use change) and forest degradation (the loss of biomass and within forests that remain forests), contributing to changes in forest carbon densities over whole landscapes and to $\mathrm{CO}_{2}$ emissions [5-7].

Although deforestation is the major contributor to carbon emissions in many tropical countries, degradation (understood here as the loss of woody biomass in forest that remains forest, and often referred to by foresters as 'disturbance') is also a considerable source of emissions at a national level [8-10]. This is because although activities which cause degradation result in relatively low carbon stock losses per hectare per year, such activities are very widespread and affect a large proportion of all forests. The losses per hectare due to deforestation are much higher, but the area affected is usually much smaller. There have been large numbers of studies investigating causes and costs of deforestation [11-18] but far fewer focusing on the causes of degradation $[10,19,20]$, despite the importance of degradation as a contributor to carbon emissions [21-23]. Localized studies on degradation have often identified the drivers (selective logging, fires, shifting cultivation, extraction of wood for fuel, etc.) but have not attempted to quantify their impacts or their relative importance [24-26], sometimes even confounding 
degradation with deforestation (e.g., [27] for the case of Ghana, [28] for the case of Kalimantan). Global studies of degradation have attempted to estimate the total effect, but with a high level of uncertainty about the contribution of the different drivers [6,29]. In practice, much depends on whether shifting cultivation is considered a driver of degradation or of deforestation [29].

Recent publications $[25,30,31]$ now accept that shifting cultivation is more often associated with degradation than with deforestation, and suggest that globally the main drivers of degradation, in order of importance, are selective felling for timber; shifting agriculture; and the use of wood for charcoal, fuelwood, and construction materials. The collection of leafy material for fodder and use of forests for grazing are also sometimes acknowledged as drivers, but their relative importance has never been studied. However, by no means will all these drivers be present in all cases, and their relative importance will depend on the local context. In the case study area discussed in this article, for example, earlier studies have indicated that there is very little timber available, charcoal is not being produced, and firewood is being extracted at a relatively low rate [32,33]. The significant drivers of degradation here are temporarily clearance for shifting cultivation or pasture, extraction of poles for fences, and free grazing of cattle in the communal forest areas.

In many places where rural households extract forest products to maintain their livelihoods, policy interventions such as payment for environmental services schemes have been initiated. These involve direct payments to rural households, or to rural communities as a whole, under the assumption that such payments would offset the need for the activities causing deforestation and forest degradation. The underlying principle is that decreases in forest income due to restrictions on household use of forest resources (i.e., the opportunity costs) would be compensated [14,19]. However, these national and international initiatives routinely and implicitly assume that communities are internally homogeneous in socio-economic terms (usually all members of rural communities are considered to be poor). The policies may acknowledge that women's voices and needs are not fully taken into account, but they almost universally ignore the fact that there are richer and poorer farmers within most communities, as well as the fact that the use of forest resources is likely to vary according to these class differences.

This is despite the fact that it is well known that poorer households depend more on forest products in their livelihood strategies, although wealthier households use greater amounts of natural resources in total $[19,31,34,35]$. These studies confirm that the income that people derive from forest varies considerably between local users and will be different for landless people and for farmers of different types within a community. At the same time, it has been noted that national policies that promote the dissolution of communal lands and strengthen individual property rights at the local level may increase inequalities in land tenure [36]. In the context of the present study in Mexico, two such effects can be seen. Firstly, agricultural land is becoming more concentrated in the hands of the better-off farmers $[37,38]$, and secondly, community forest lands that were originally under common property management and accessible to all have in many cases been carved up and privatized $[39,40]$. This puts at a disadvantage those farmers who have no individual rights to land and who earlier would have depended largely on access to the common property forests [40,41]. This process of land tenure change may be expected to exacerbate on-going class divisions within communities, increasing the differentiation in uses that people make of forests, which in turn may have significant effects on rates of deforestation and rates of degradation.

The starting assumption of our analysis is therefore the existence of different farmer classes within agricultural communities in Mexico, and the reality that some farmers within communities are landless, which will be reflected in their use of forests and the role that forests play in their differentiated livelihoods. Our stand point is not so much that programs such as Deforestation and Forest Degradation (REDD+) should take these differences into account for moral reasons relating to equity, although we are very aware of this issue, and moreover see that resolving it may be necessary for legitimacy of the program. Instead, our main argument is that these differences need to be taken into account for reasons of effectiveness and efficiency. Incentives to change behavior should arguably, 
for reasons of effectiveness and efficiency, reflect the opportunity costs faced by different groups [19]. Above all, the groups that are most responsible for degradation may need to be specifically targeted; paying those who are not involved in degrading the forest resources may be considered wasteful from a simple economic standpoint. Hence, a better understanding of the socio-economic aspects of degradation processes at the local level is needed.

We performed a study designed to estimate the factors driving forest degradation in communities where temporary land use clearance for shifting cultivation is common, thus explaining increased or continued degradation. We applied an ordinary least squares regression to examine the effects of key decision-making variables on temporarily clearance of land, specifically of the degradation processes, through a detailed analysis of farmer strategies, including better-off and landless farmers, using data from the field.

For the study, we took the case of agrarian nuclei (known as ejidos) in the tropical dry forest (TDF) zone in western Jalisco. These areas have been subject to human uses for many generations, and shifting cultivation and free range grazing has led to forest degradation, while clearance for permanent agriculture and pasture has led to deforestation. We found that richer and poorer farmers actively participate in activities causing forest degradation, but it is the wealthier farmers that are making more temporarily clearances compared with farmers with less resources.

\section{Materials and Methods}

\subsection{Empirical Specification}

The factors that may be influencing the amount of temporarily clearance of land for shifting cultivation, as well as its consequent degradation, can be evaluated by an ordinary least squares (OLS) regression model [42], as linear models allow the decomposition of the value of the dependent variable in a regression model (total amount of land cleared temporarily for shifting cultivation in this study). Regression analysis is an approach often used to evaluate spatial patterns relating to land cover changes $[11,42,43]$ and to obtain a measure of the factors that influence in the amount of forest conversion. Analyses of land use change and deforestation are usually based on mapped and remotely sensed spatial data from different periods to identify cleared fields and to determine the main drivers and constraints of the change [44-46]. In our case, earlier studies had already clearly established that large parts of the area, particularly the slopes with TDF, were heavily degraded [33,47,48]. Building on this, the current study aimed to measure and test the influence of the variables that determine the number of hectares cleared for shifting cultivation by an individual farmer.

This study analyzes farmers' individual choices with regards to temporarily clearance of TDF for shifting cultivation or grazing on the basis of survey responses. The form of the dependent variable was continuous, indicating the total amount of land cleared for shifting cultivation in the previous year of the survey, and the starting hypothesis was that this amount may depend on a series of variables, explained in more detail below (Table 1).

Table 1. Independent variables used in the statistical model of factors contributing to forest degradation and their associated descriptive statistics.

\begin{tabular}{|c|c|c|c|c|}
\hline Variable & Definition & Mean & SD & $\begin{array}{l}\text { Hypothesized } \\
\text { Sign }\end{array}$ \\
\hline \multicolumn{5}{|c|}{ Main independent variables } \\
\hline Ln_Pole & $\begin{array}{l}\text { Log of total annual fencing poles extracted } \\
\text { by farmer }\end{array}$ & 2.52 & 2.07 & Positive \\
\hline Cattle & Number of cattle per farmer & 8.83 & 14.73 & Positive \\
\hline
\end{tabular}


Table 1. Cont.

\begin{tabular}{|c|c|c|c|c|}
\hline Variable & Definition & Mean & SD & $\begin{array}{l}\text { Hypothesized } \\
\text { Sign }\end{array}$ \\
\hline \multicolumn{5}{|c|}{ Control variables } \\
\hline Tot_Pop & Total population in the sampled communities & 873.09 & 970.77 & Positive \\
\hline $\begin{array}{l}\text { Marginalization } \\
\quad \text { index }(M I)\end{array}$ & $\begin{array}{l}\text { Marginalization index (based on income, } \\
\text { education levels, and living conditions) }\end{array}$ & 7.91 & 2.62 & Positive \\
\hline Road & $\begin{array}{c}\text { Dummy variable, } 1 \text { if a road exists in less than } \\
1 \mathrm{~km} \text { from the land; } 0 \text { otherwise. }\end{array}$ & 0.77 & 0.41 & Positive \\
\hline Slope & $\begin{array}{l}\text { Dummy variable, } 1 \text { parcel is located on the } \\
\text { hillsides; } 0 \text { parcel is located on flat lands }\end{array}$ & 0.59 & 0.49 & Positive \\
\hline $\begin{array}{l}\text { Tropical dry } \\
\text { forest (TDF) }\end{array}$ & $\begin{array}{l}\text { Total area of tropical dry forest owned by } \\
\text { farmer (ha) }\end{array}$ & 13.87 & 24.21 & Positive \\
\hline Fam_Size & Number of members in the household & 4.09 & 2.04 & Positive \\
\hline \multicolumn{5}{|c|}{ Dependent variable } \\
\hline $\begin{array}{c}\text { Shifting } \\
\text { cultivation (SC) }\end{array}$ & $\begin{array}{l}\text { Total amount of land temporarily cleared for } \\
\text { shifting cultivation in the past year (ha) }\end{array}$ & 1.92 & 2.98 & \\
\hline
\end{tabular}

\subsection{Data}

To investigate and understand the proximate drivers that contribute to farmers' individual decisions to temporarily clear forest for shifting cultivation and grazing, we asked farmers to describe the stages typically involved in permanent cultivation, shifting cultivation, and grazing practices in the area of study.

Field work, pre-test interviews, and a literature review were useful in identifying the factors involved in the understanding of the amount of temporarily cleared TDF for shifting cultivation in the Ayuquila basin. A priori, we expected to find shifting cultivation in the hilly areas, and that this activity would be more associated with poor farmers. In addition, we hypothesized that the incentives affecting the decision to temporarily clear TDF for shifting cultivation would differ among socio-economic farmer groups.

We carried out a survey to obtain data for our dependent variable and main independent variables. In addition, we compiled socioeconomic data at the community level from the National Population Council of Mexico.

The variable shifting cultivation (SC) is the dependent variable indicating the total amount of $\mathrm{TDF}$, in hectares, 1 placed under shifting cultivation agricultural system in the past year. We included physiogeographic variables and socio-economic information among the control variables (Table 1).

We related the total amount of land temporarily cleared for shifting cultivation (SC) to the associated variables of temporarily clearance identified in the surveys (see Section 2.5) and the literature review:

$$
\mathrm{SC}_{\mathrm{i}}=\beta_{0}-\beta_{1} \text { LnPole }_{i}+\beta_{2} \text { Cattle }_{+} \beta_{3} \text { Tot_Pop }_{-} \beta_{4} \text { MI }_{i}+\beta_{5} \text { Road }_{i}+\beta_{6} \text { Slope }_{i}+\beta_{7} \text { TDF }_{i}+\beta_{8} \text { Fam_Size }_{i}
$$

where $L n_{-} p o l e_{\mathrm{i}}$ is the logarithmic transformation of the number of wood fence posts extracted by the farmer from his land; Cattle denotes the number of head of cattle owned by farmer; $\mathrm{TDF}_{\mathrm{i}}$ denotes the total land covered with tropical dry forest owned by the farmer; Tot_Pop $\mathrm{P}_{\mathrm{i}}$ is the total population living in the community of observation ; $M I$ is an index based on socio-economic characteristics of households calculated by the government of Mexico; Road $_{\mathrm{i}}$ is a dummy variable for coding the parcel proximity to a road or dirt road; $S_{\text {Sope }}$ is related to topography, coded as a dummy with value one when the parcel is located on hilly areas and zero for flat areas; $\mathrm{TDF}_{\mathrm{i}}$ denotes the total land covered 
with tropical dry forest owned by the farmer; and Fam_size indicates the number of family members living in the household. The terms $\beta_{\mathrm{s}}$ are parameters that will be estimated from the data through the linear regression model.

The regression analysis and data processing were undertaken using version 15 of STATA statistical package (StataCorp. 2017. Stata Statistical Software: Release 15. College Station, TX, USA: StataCorp LLC.).

\subsection{Hypotetized Effect of Variables Included in the Model}

Fencing poles are an important by-product and a source of income for both landless farmers and ejidatarios (farmers with rights to land) because it is a common practice to sell poles to any farmer in possession of cattle; thus, the $L n \_$poles variable is expected to have a positive sign. Several researchers maintain that livestock grazing in forests is considered a driver of forest degradation [25,30,49-51]. Hence, the ownership of livestock was also expected to increase the amount of temporarily land use change because (as indicated above) shifting cultivation is a common way of obtaining cheap maize crop residues that will be used as fodder. Total population in the community was expected to have a positive effect on the amount of land cleared for shifting cultivation, as previous studies explained the importance of population pressure as a primary factor for land use changes [52]. The marginalization index $(M I)$ is an indicator of the socio-economic conditions and poverty at a local scale in Mexico. The $(M I)$ used in this study is based on a 0 to 100 scale, wherein lower levels are associated to poor wellbeing.

Previous studies have suggested that the opening of new roads lowers access costs and therefore increases deforestation and land clearance for shifting cultivation [25,30]; hence, the expected sign of the coefficient of the Road variable was positive. A priori, we expected to find shifting cultivation in the hilly areas; thus, the expected sign of the Slope variable was positive.

To deal with the question of scale, the size of TDF holdings per farmer was included and was expected to have a positive effect on the total amount of cleared land for shifting cultivation. Finally, having more members in a household was expected to have a positive effect on the total amount of land cleared for shifting cultivation, as shifting cultivation is often described as a traditional subsistence farming.

\subsection{Study Area}

The study area is centered in the basin of the Ayuquila river in the state of Jalisco, Mexico (Figure 1), an area that was selected as a REDD+ early action area at sub-national level by the National Forestry Commission (CONAFOR) of Mexico. The study site encompasses 10 municipalities with an area of about $4200 \mathrm{~km}^{2}$ and is situated at an altitude range between 250 to $2500 \mathrm{~m}$ above sea level. The areas at the higher elevations (1800 to $2400 \mathrm{~m}$ above sea level) are covered by firs (Pinus Abies L.) and pines (Pinus spp.), with pine and oak species (Pinus-Quercus S.) associations lower down the slope, followed by deciduous tropical dry forest (TDF) at elevations of 400 to $1200 \mathrm{~m}$ above sea level, which form the dominant natural ecosystem in terms of area. The TDF provides high biodiversity and other ecosystem services such as fresh water, wildlife, and non-timber forest products. Rain falls mainly during the summer months, and the mean annual precipitation between 2004 and 2012 was $950 \mathrm{~mm}$, whereas the mean temperature for the same period was about $21^{\circ} \mathrm{C}$. In terms of human use, all suitable low lying level areas have been permanently converted to agriculture, which has been the case for many years. However, the wooded slopes, particularly in the TDF zone, are typically used for cycles of shifting cultivation and temporary grazing, and have been degraded as a result, as demonstrated by several studies of canopy cover using remote sensing $[33,47,53]$. In recent years, level areas at higher altitudes are increasingly being cleared of forest and converted into permanent agriculture or pasture, although this is in most cases illegal. 


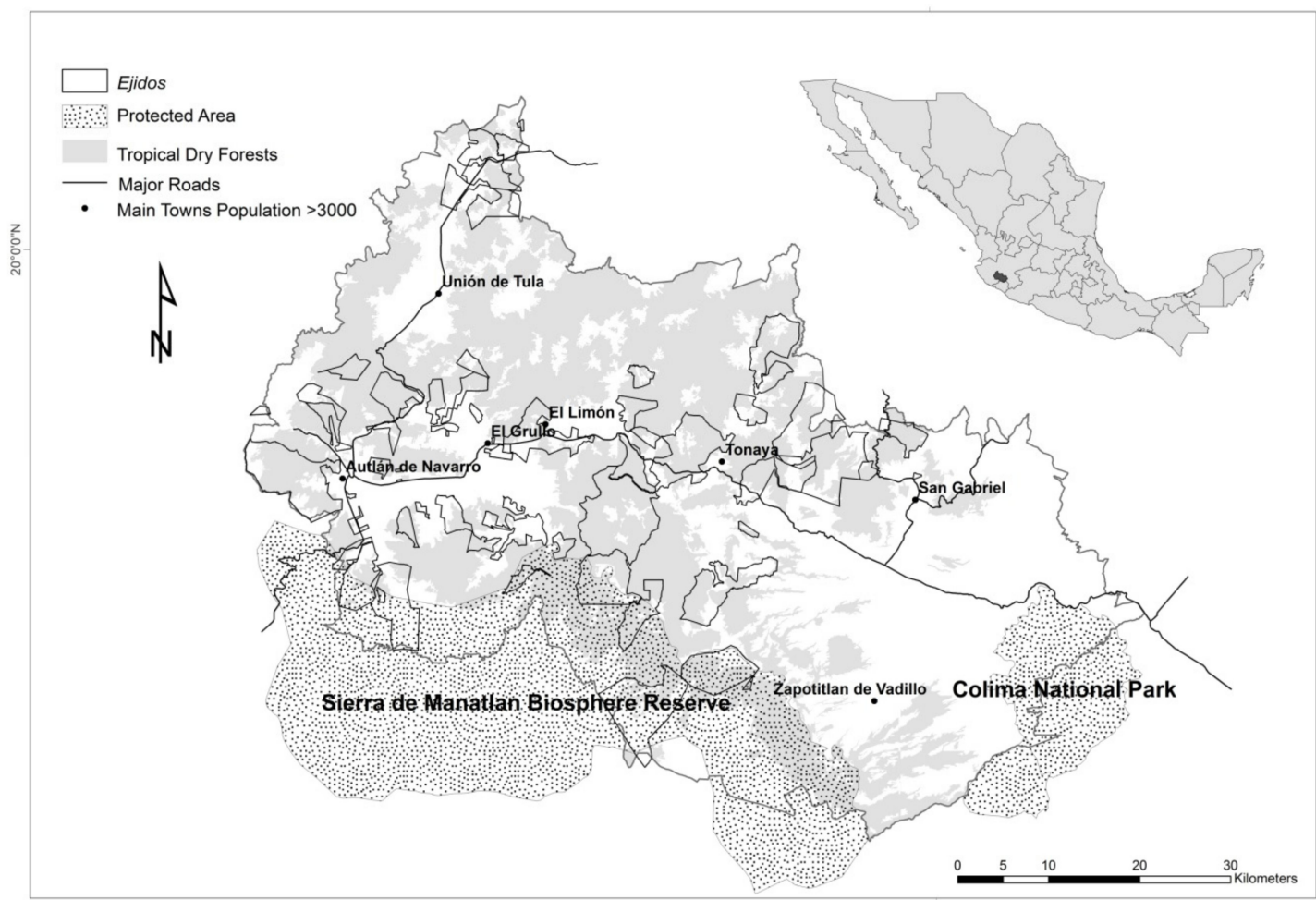

Figure 1. Regional map of the study area showing the 31 sampled agrarian nuclei (ejidos) within the Ayuquila Basin, Jalisco, Mexico.

Within the municipalities of the sample there are many ejidos. These are agrarian nuclei which are regulated by the agrarian law and by their own internal council and assembly; most have a population of less than 3500. An ejido represents a communal resource-holding system; most were established by the government between 1930 and 1950 . The land is owned by the community as a whole, but is shared by the members; each member has rights to use a particular plot for agriculture. Members are called ejidatarios and they may pass their land and assembly voting rights on to one of their children as inheritance. In addition to the ejidatarios, however, there are other groups of people living in the community who do not have land rights (e.g., families of the children who did not inherit rights, or immigrants from other areas). These families are not considered official members of the community and may either rent land from ejidatarios, or work as laborers.

The territory of ejidos is generally divided into (a) an urban area with houses and garden lots, (b) individual parcels for agriculture, and (c) a common access land which is usually covered with forest and/or rough pasture. This common area is not supposed to be cleared of forest, but is customarily utilized by local inhabitants for temporarily agriculture (shifting cultivation) and for free ranging cattle (there is little timber of commercial value in the TDF zones). The last 20 years have witnessed a gradual process of individualization, which had started even earlier but was stimulated by an agrarian reform law in $1992[39,40]$. This gave ejidos the possibility, if so decided by their assemblies, to allow personal land titles to be issued to ejidatarios for their individual plots of agricultural land. In the area of the study, it can be seen that in many ejidos, common use lands are also being split among ejidatarios for their individual use. There has also been a certain amount of sale of land and associated rights between ejidatarios. There are also many people living within the community who do not have land, either because following the agrarian reform law they had sold it to other ejidatarios, or because they never had land rights (non-ejidatarios). These people may work as laborers for ejidatarios with larger properties, or may rent land by the year, often on a share-cropping basis, typically with crop residues remaining as the property of the owner. 


\subsection{Land Use Practices of Farmers in the Sample}

Agriculture, cattle farming, and mixed crop-livestock systems are practiced both by landholders (ejidatarios) and by landless people who may rent the land from them. Farmers in the sample practice two main types of farming: (1) intensive permanent farming in the lowland areas, in which the yield per hectare is relatively high as a result of using fertilizers and pesticides; and (2) shifting cultivation on the slopes, in which the per hectare yield is lower and the crops are grown for 3 to 4 years followed by a forest fallow of 3 to 10 years. Many also raise cattle. In addition to producing crops, agriculture of both types provides green fodder for livestock in the form of crop residues after the harvest, and shifting cultivation in addition provides by-products such as building poles, firewood, and pasture for cattle during the fallow period, among other useful items. As noted above, intensive agriculture in the lowland areas has led to permanent clearance of TDFs, and fertilizer use is essential to maintain fertility, whereas the practice of shifting cultivation results in temporary clearances with rapid secondary re-growth of forest, such that most of the forest in this area can be considered degraded. Little or no fertilizer is used, and the extent of soil depletion depends on the length of the fallow.

As observed in the field, farmers with land in fertile low lying areas usually operate a permanent agriculture system; this land is not typically dedicated to shifting cultivation, and the farmers who own this land are usually among the richest in the community. We expected, therefore, to find that these farmers would have less propensity to temporarily clearances for shifting cultivation.

Usually, the area under permanent agriculture is important in the food supply chain, as it is intended for national markets, whereas shifting cultivation production is mainly for own consumption and to a lesser extent for sale within the communities. Cattle are held primarily for external sale.

These economic activities have affected the forest species composition, especially in TDF, and to some extent in pine forest and oak pine forests. However, these forests remain an important source of firewood, poles, medicinal plants, and foodstuffs for local people. Land use choices in the study site are strongly influenced by the topography of the land and micro-climates. To reach a better understanding of the factors that contribute to forest degradation, a description of the activities that are typically involved in permanent cultivation, shifting cultivation, and grazing in the area of study is provided.

\subsubsection{Permanent Agriculture System}

Farmers in the study sample who practice permanent cultivation in the plains area sow maize, mainly under rain-fed conditions; this is often called the seasonal maize crop. They sow in the rainy season (June-July) and harvest in November. After the maize harvest, crop residues are used for livestock feed, often through in situ stubble grazing. The activities needed for land preparation include subsoil ploughing, raking, sowing, and sealing, all of which require labor and inputs such as seeds, pesticides, fertilizer, and tractors.

A few farmers grow maize under irrigated conditions, enabling them to obtain two harvests a year. Under irrigation, labor and material input supply are similar to those in seasonal maize crops; however, more financial and capital investment is required. Again, crop residues are an important by-product, and farmers crush these for livestock feed as ex situ forage.

Most farmers in the sample who sow under permanent cultivation have used these lands for many years. There is virtually no more low-lying land that could be converted for permanent cropping agriculture within the community boundaries. However, as a result of informal and/or illegal parcelization of the commons area, some level areas at higher elevations have recently been cleared for permanent cropping of maize or for pasture, and there have also been small patches of clearance on the slopes utilized to create permanent pasture.

\subsubsection{Shifting Cultivation System}

Before the rainy season, farmers select areas covered by TDF on the hillsides. Land preparation starts with cutting down trees in a given area in order to remove the old vegetation. Clearing land 
provides some materials such as firewood and fencing poles to the shifting cultivators. Firewood is a major source of domestic energy and provides an important source of income for people in rural areas, whereas fencing poles are needed to keep cattle within specific landholdings. The remaining material will be moved together into piles and left to dry, and is later burned.

Cultivators will leave small trees to speed regeneration during the fallow period; these are also used to provide shadow for the livestock after the harvest. In preparing land, the use of fire supplies ashes, which function as fertilizer for the soil during the first two years, although in years 3 and 4 , a small quantity of chemical fertilizer may be used to supply a portion of the maize crop's nutrient needs. Pesticides are not used. The land is not ploughed-planting is carried out by making holes to drop maize seeds in. A common practice in the shifting cultivation system is to mix cropping, such that in addition to maize, beans and squash are planted in the same field. The maximum cultivation period of land will be three or four years and then it will be left to fallow. During the dry season and in the fallow period, these temporarily agricultural plots provide significant opportunities for grazing and form an important source of fodder.

\subsubsection{Cattle Grazing Practices}

Livestock have traditionally been used as a living savings account, as cattle can be converted into cash when necessary in order to cover unexpected expenses such as illness, a death of a family member, or a wedding, among other factors.

Traditionally, woodlands and pastures remained in common use and were unfenced; thus, farmers who owned livestock used to release cattle for grazing on the common access, uncultivated lands at the start of the rainy season. During the dry season, corn, stubble, crop residues, or purchased feed were used as the main provision of animal fodder.

In the last five years or so, many farmers have become interested in investing in more livestock, owing to their increasing market value in comparison to maize. Cattle are increasingly kept and fattened up for sale. However, before the purchase of additional animals, cattle farmers need to make sure they have enough land for cattle grazing, as the availability of feed from the crop land in the post-harvest season is limited, whereas purchased feed is expensive.

The need for land for livestock raising, among other reasons, has prompted several ejidos to promote individualization through territorial subdivision of the common use land and the creation of individual property rights over these common resources for the members of the ejido, causing the consequent dissolution of the commons. After the subdivision of common lands, cattle will graze on the newly privatized, fenced, forested parcels that belong to the ejidatario, rather than being free to roam the whole common area. Although non-ejidarios may, by common agreement, be allowed to continue gathering firewood over what used to be the common lands, they are unlikely to be allowed to send their cattle to graze there, unless by a special arrangement wherein they rent a piece of fenced pasture from the owner.

Where common forest lands have been assigned to individual use, some farmers have not only fenced them for private use, but have also established permanent pasture or permanent agriculture if slope conditions permit, done by clearing the forest patch completely-although this is officially not permitted. The conversion of forested area to create permanently cleared spaces in common access lands results in deforestation, whereas the earlier system of free grazing in the forested areas resulted only in degradation. Farmers do this because induced grassland provides more and better quality fodder for the cattle, or, if they are fortunate enough to have acquired a level piece of land on the brow of the hill slope, it is possible for them to grow maize, also often used for fodder. However, quite apart from this (illegal) permanent clearance, the parceling of common land may form a stimulus for farmers to acquire more cattle, and this may increase the demand for fodder, leading to the opening of yet more shifting cultivation areas, as these yield fodder both between the growing seasons and during the fallow period. 
Because of the increasing herd sizes in most ejidos, crop residues represent an important source of income for small-scale farmers (who can sell them if they do not have cattle of their own), as well as for farmers in possession of the larger plots in the ejido. It is a common practice for large landowners to rent part of their hillslope land to landless and poor farmers who pay in kind (a share of the crop), with the mutual agreement that the crop residues will be left to the landowner for livestock feed.

\subsection{The Sample}

Data were collected in the field in the summer of 2013. A sample of 31 agrarian nuclei (Figure 1) was selected within the Ayuquila basin, including a total of 301 personal interviews. The sampling frames were obtained from official lists of households provided by local authorities, and the sample size within each agrarian nucleus was proportional to population size to ensure a balanced representation. The survey was administered by five students from the university, and interviews lasted $30 \mathrm{~min}$ on average.

The sample included not only farmers with official titles to land under the ejido system, but also other farmers such as renters and share croppers within the communities. Women rarely hold the land right and rarely consider themselves to be 'farmers'; the women ejidatarios interviewed were mostly widows who inherited their land right from their husbands, usually renting this land out to other people.

The study uses data on the actual choices taken by farmers to estimate the effects of selected explanatory variables on temporary clearance of land for shifting cultivation. The survey gathered information on agricultural and cattle ranching practices and socio-economic characteristics such as land holding size, and these were used to model smallholder land use practices. The date for this article can be found in Supplementary Materials.

Photographs were used to help in identifying types of slope farmers usually cultivate and the frequency with which they clear trees or shrubs to cultivate crops or grassland. Respondents also provided information about their farming habits, such as seasonal crops, travel time, tenure, the length of time for which the land is used for agriculture, and the period for which the land has to be abandoned for land recovery (fallow period), as well as questions relating to their income from their agricultural activities. Then, the survey gathered detailed information about consumption of other forest resources and whether these are collected by themselves or purchased. The list of natural resources included items such as fruit and wild foods, timber, firewood, fencing poles, and medicinal plants, among others. To complete the questionnaire, socio-demographic data were collected (e.g., gender, education level, forest income, total annual income, etc.).

As the survey was carried out in the sowing season, it was often difficult to contact farmers whose working day ranged from 10 to $12 \mathrm{~h}, 6$ days per week. Sometimes farmers had to be reached while working in their parcels and sometimes during lunch, at home. No major problems were found in the surveying process, as $97 \%$ of respondents agreed to answer the questions once they were contacted.

The questionnaire was pre-tested with farmers, as well as through meetings and conferences in the area of study, which also facilitated an understanding of the current situation of farmers. In addition, discussions with local people and open interviews with community leaders were useful in understanding farmers' preferences, decisions, and practices, as well as in identifying variables that could have an influence on land use decisions in the region. Before the final version of the questionnaire, several one-on-one interviews were conducted to ensure that the questions were clear to respondents, and to verify that the language used in the questionnaire was adequate.

\section{Results}

\subsection{Distribution of Farmers in the Sample by Land Use Types}

Responses were first divided between two main farmer groups: (1) those who had cleared land in the TDF area during the past 20 years, and (2) those who had not. Then, the group that had cleared land 
was divided into those who cleared only to establish permanent cultivation or pasture (i.e., permanent clearance classified as deforestation), those who cleared only for shifting cultivation (classified as forest degradation), and those that cleared both for shifting cultivation and permanent cultivation or pasture (Figure 2).

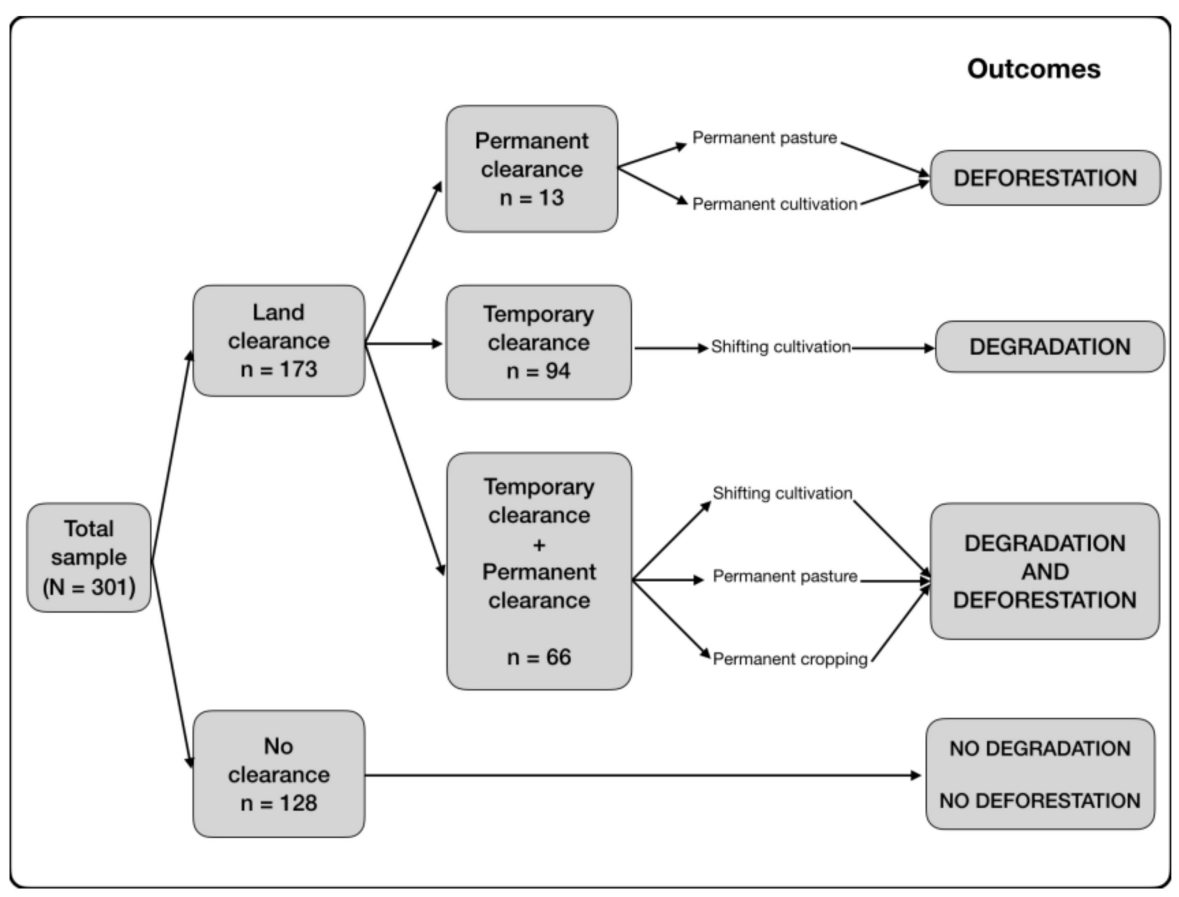

Figure 2. Typology of farmers in the sample according to agricultural land use type.

Descriptive statistics from the 301 in-person interviews showed that $43 \%$ had not cleared land at all in the last 20 years, and that 57\% had cleared land in TDF areas over the last 20 years. Somewhat more than half of this group had cleared only for shifting cultivation, $4 \%$ had cleared land but only for permanent agriculture uses, and the rest had in addition also cleared to establish shifting cultivation. Table 2 reports the socio-demographic characteristics and types of land use for each group of farmers.

Table 2. Socio-demographic characteristics of farmers in the sample by land use types.

\begin{tabular}{|c|c|c|c|c|c|c|}
\hline & \multicolumn{2}{|c|}{ No Land Cleared } & \multicolumn{4}{|c|}{ Land Cleared } \\
\hline & Landless & Landowners & $\begin{array}{l}\text { Temporary } \\
\text { Clearance } \\
\text { for Shifting } \\
\text { Cultivation }\end{array}$ & $\begin{array}{l}\text { Permanent } \\
\text { Clearance }\end{array}$ & & $\begin{array}{l}\text { Temporary } \\
\text { and } \\
\text { Permanent } \\
\text { Clearance }\end{array}$ \\
\hline Sub-sample size & 29 & 99 & 94 & 13 & & 66 \\
\hline Age (years) & 48 & 63 & 77 & 59 & & 67 \\
\hline Gender (percentage male) & 100 & 90 & 90 & 100 & & 95 \\
\hline Education (years) & 5 & 5 & 3 & 3 & & 5 \\
\hline Household members & 5 & 4 & 6 & 4 & & 5 \\
\hline $\begin{array}{c}\text { Firewood users } \\
\text { (percentage) }\end{array}$ & 76 & 73 & 90 & 70 & & 73 \\
\hline Landowners (percentage) & 0 & 100 & 52 & 95 & & 85 \\
\hline $\begin{array}{l}\text { Working years in } \\
\text { agriculture }\end{array}$ & 23 & 43 & 39 & 43 & & 36 \\
\hline $\begin{array}{l}\text { Head of cattle } \\
\text { Type of land use }\end{array}$ & 2 & 6 & 4 & 6 & & 17.5 \\
\hline Cultivated area (ha) & 3 & 6 & 1.2 & 7 & $\begin{array}{l}\text { Permanent } \\
\text { SC }\end{array}$ & $\begin{array}{c}9.5 \\
4\end{array}$ \\
\hline Pasture (ha) & 0 & 1.5 & 0.5 & 2.5 & & 2.5 \\
\hline TDF (ha) & 0 & 5 & 3.3 & 2.5 & & 16 \\
\hline
\end{tabular}


Of those who had not cleared any land in the last 20 years, three quarters have permanent plots which average 6 hectares, while the others are landless and support themselves through selling their labor (in a very few cases they rent agricultural land on a share crop basis). This means that the non-clearing group is of mixed socio-economic character: (1) the landless farmers, the youngest among subsamples who have been involved in agricultural activities for only 20 years (i.e., as labourers), having considerably less experience than the other groups. Many had initially worked in activities different from agriculture (e.g., grocery store, mechanic's shop, taxi driver), and others have a main economic activity that is not in the primary sector-for them, agriculture is part-time work; (2) the owners of land who did not clear any land in the last 20 years for whom agriculture is and always has been their main livelihood. What the data show is that overall around one third of all the farmers in the survey are not engaged in degradation-causing activities because they only operate plots that were cleared long ago, while a small proportion $(10 \%)$ are not engaged in degradation-causing activities because they are too poor even to rent land, or they have other sources of income and do not rely much on agriculture.

The group of farmers clearing land temporarily and only for shifting cultivation (about 30\% of the total sample) are the oldest among the farmer sub-groups. They have the largest family size (six members), have received the least formal education, and represent the highest percentage of firewood users, mainly for cooking purposes. More than 50 percent of these rent their land from landowners (eijidatarios) or borrow it in return for the maize residues that are used as cattle fodder. This group of farmers cultivate an average of 1.5 hectares, and, for most of them, agriculture remains the main income-generating activity. All these characteristics indicate that this group represents the poorest farmers in the community.

A relatively small group of farmers have cleared land, but only for permanent uses within the last 20 years; they do not have any shifting cultivation plots ( $4 \%$ of the total sample). They are almost 20 years younger than farmers in the shifting cultivation system, and their mean household size consists of four people. Most of these farmers (95\%) own their land, sow about 7 hectares, and have almost 45 years' experience. Most of these characteristics suggest that they are much better-off than the shifting cultivation farmers.

It is interesting to note that the wealthiest group of farmers in the sample consists of those who have cleared both to create permanent pastures or agriculture in the TDF and for shifting agriculture. Their newly cleared permanent plots are larger than those of the farmers who have only permanent plots; around $25 \%$ of area cleared was destined for permanent pasture and $14 \%$ for permanent cropping (maize). In addition, they opened shifting cultivation plots, primarily to secure fodder for cattle. The majority in this group are landlords and private landowners who come to a verbal agreement with landless farmers in which a certain area of land is handed over to them on a crop-sharing basis for a specified period of time with the understanding that the landowner will use maize residues. In some cases, shifting cultivation plots may later be converted to pasture, rather than being allowed to follow the traditional cycle through an extended fallow period. Indeed, this is a route often used to circumvent the local bylaws and norms that are intended to prevent permanent clearance of forest. After cultivation for four years, the owner may simply claim that the area never really was forest, justifying his 'improvement' by sowing fodder grasses.

\subsection{Multivariate Regression Models of Forest Degradation by Farmer Group}

We conducted two regressions using the amount of cleared land in the TDF in the past year as the dependent variable, dividing the respondents now into two groups, the richer and the poorer. This way we could test whether these groups have the same variables relative to explaining the amount of temporary clearance for SC. Table 3 shows the estimates of the variables related to temporary land use change for the shifting cultivators group (SC group or temporary clearance for SC) and the permanent agriculture and shifting cultivators group (PA\&SC, the wealthiest farmers group or those that cleared land both for shifting cultivation and permanent cultivation/pasture), as presented in Table 2. 
Table 3. Estimated coefficients of the factors affecting forest degradation in the Ayuquila Basin, Jalisco, Mexico.

\begin{tabular}{ccc}
\hline Variable & Shifting Cultivators' Group & $\begin{array}{c}\text { Permanent } \begin{array}{c}\text { Agriculture and Shifting Cultivators (PA\&SC) } \\
\text { Farmers Group }\end{array} \\
\text { Ln_Pole }\end{array}$ \\
Cattle & $0.1477^{* * * *}$ & \\
& $(0.0396)$ & $0.0110^{* * *}$ \\
Tot_Pop & & $(0.0054)$ \\
& $0.0002^{* * *}$ & 0.0000 \\
MI & $(0.0000)$ & $(0.0000)$ \\
& $0.0764^{* * *}$ & 0.0162 \\
Road & $(0.0302)$ & $(0.0448)$ \\
& 0.0159 & -0.1902 \\
Slope & $(0.1793)$ & $(0.2313)$ \\
& $0.5853^{* * *}$ & -0.0557 \\
TDF & $(0.2977)$ & $(0.3030)$ \\
& $0.0103^{* * *}$ & $0.0089 * * *$ \\
Fam_Size & $(0.0049)$ & $(0.0030)$ \\
& 0.0099 & -0.0209 \\
Intercept & $(0.0384)$ & $(0.0502)$ \\
$R^{2}$ & -1.6126 & 0.8842 \\
$p$-value & $(0.6636)$ & $(0.7197)$ \\
Sample & 0.31 & 0.21 \\
& $<0.001$ & $<0.05$ \\
& 89 & 66 \\
\hline
\end{tabular}

Standard errors in parenthesis; $* * *, * *$ Significance at $1 \%, 5 \%$.

We used a traditional ordinary least squares (OLS) using a semilogarithimc function where the dependent variable is the natural log of the quantity and is interpreted in percentage terms. A logarithmic specification provided the best fit in comparison to several linear and nonlinear specifications.

The $F$-values of the RESET tests in both regressions were $F(3,56)=0.21$ for the SC group and $F(3,78)=0.18$ for the PA\&SC group, and their corresponding $p$-values of 0.18 and 0.89 were above the conventional significance level of 0.05 , indicating that the semilogarithmic models were adequate in both regressions. The White's test shows that heteroskedasticity did not exist in our models. The values of (prob $>\chi^{2}=0.51$ ) for the SC group and (prob $>\chi^{2}=0.09$ ) for the PA\&SC group were above the $5 \%$ significance level; thus, we failed to reject the null hypothesis of homoskedasticity. The results showed that the residuals from both samples followed a normal distribution (the Skweness-Kurtosis test was $p=0.69$ for the SC model and $p=0.24$ for the PA\&SC model).

All parameters in the SC model, but two, were significantly different from zero at least at the 5\% level and had the expected signs. Results for the SC model suggested that farmers in need of extracting poles contribute to the increase of forest degradation in the area of study $(\beta=0.14, p<0.01)$. A log transformation was used to reduce variation in the number of extracted poles by individuals and also because the logarithmic specification resulted in a better fit than an alternative non-logarithmic specification of the fencing poles variable. The variable transformation reflected a decrease in the number of extracted fencing poles with time; in this sense, more posts are needed when a wooden fence is first built, whereas in the following years farmers usually just replaced damaged, broken, or rotten fencing posts. Population growth (Tot_pop variable) was significant at the $1 \%$ level $(\beta=0.0002, p<0.01)$ and had a positive effect on the amount of temporarily clearance for shifting cultivation in the study area. The Slope variable (hilly areas) was significant in the model and significant at $5 \%(\beta=0.58, p<0.05)$, suggesting that physiogeographic characteristics of land are key factors for this agriculture system because of its low capital requirements as a farming system primarily of the poor. The amount of TDF owned by farmers in the SC group was positive and significant at the $1 \%$ level $(\beta=0.01, p<0.01)$, suggesting that the larger the area of TDF available to an individual, 
the greater the amount of cleared plot for the purpose of shifting cultivation. The overall model fit was $R^{2}=0.31$.

Results for the PA\&SC model showed only two explanatory variables significantly different from zero. As expected, the Cattle variable was positive and significant at the $5 \%$ level $(\beta=0.01, p<0.01)$, suggesting that the presence of livestock increases the probability of clearing for temporary pastures. Similar to the SC regression model, the amount of TDF owned by farmers in the PA\&SC group was positive and significant at the $1 \%$ level $(\beta=0.08, p<0.01)$, suggesting that the availability of TDF encourages the practice of activities related to forest degradation. The overall model fit was $R^{2}=0.21$.

A number of other socio-economic characteristics, such as age, education, and income, were tested in the model but were not significant, and thus were omitted from the final models.

\section{Discussion}

In contrast to deforestation, very few studies have been done to quantify the relative importance of drivers of the degradation processes at the local level. Most studies merely identify proximate drivers of degradation, among which are shifting cultivation and associated burning, forest grazing, and extraction of poles and firewood. This study focuses not only on these processes, but also relates them to how different classes of farmers use forest resources by modeling farmers' choices according to socio-economic and structural characteristics of rural livelihoods.

We found that the amount of land clearance for shifting cultivation increases with the availability of TDF in the community. We found evidence of this for both groups of farmers (SC farmers group and PA\&SC farmer groups); thus, independently of socio-economic class, ownership of this type of forest increases the propensity of farmers to practice activities resulting in forest degradation.

Contrary to our expectations, we found no effect between infrastructure expansion, such as new roads, and the amount of clearance. This result may be explained in association with a traditional agricultural system, in which the use of horses is the common 'transport system', as the undercapitalized farmers who practice shifting cultivation do not have trucks or tractors; hence, lack of roads or dirty roads is not an obstacle for temporarily clearance of TDF. The lack of accessibility in this agricultural system reflects lack of local development in the area.

As expected, the extraction of fencing poles is a factor affecting the behavior of the SC farmer group, whereas the main incentive of the PA\&SC group of farmers is to use their shifting cultivation plots to obtain crop residues to feed their cattle. Better-off landowners (PA\&SC farmer group) have more land cleared for shifting cultivation, although in most cases the work itself is carried out by landless farmers, as these users of land have rented or borrowed it from large landowners or ejidatarios, or work as laborers for them.

Data from our own study indicate that farmers who have only permanent fields for cultivation have no incentive to practice shifting cultivation because of their apparent agricultural specialization, whereas farmers that only have shifting cultivation fields and landowners with plots both in the valley and on the hillsides are more likely to engage in (more) temporarily clearances. The latter typically have much larger quantities of land in total, and our survey indicated that most such farmers use their shifting cultivation plots primarily for the use of the crop residues after the harvest as cattle fodder. Thus, the SC (area cleared for shifting cultivation) would be expected to have a higher value when the individual farmer has both SC and permanent agriculture plots (SC\&PA).

This brings up a very interesting conundrum. Degradation (especially that caused by shifting cultivation) is often ascribed to poverty, lack of resources, and ignorance [54-56]. In this study we show that, indeed, the poorer farmers, particularly those without land rights, tend to support their families through shifting cultivation, but this is usually on borrowed or rented land; this does not mean that they are responsible for most of the degradation in absolute terms, as the area they use is much smaller than that used for shifting cultivation by farmers with more resources. However, many of the richer farmers engage both in permanent and in shifting cultivation, and they tend to have much larger shifting cultivation plots than those who engage only in shifting cultivation (see Table 2). 
These farmers with land rights benefit by renting out their shifting cultivation land to poorer and landless farmers, taking profit directly in the form of cattle fodder.

The corollary to this is that if shifting cultivation were to be stopped, for example, under the REDD+ or Payments for ecosystem services (PES) programs, the payments would for the most part go to the owners of the plots, whereas a large number of the poorest farmers would lose the basis of their livelihoods.

If the scheme pays incentives to the community as a whole, the community usually has the choice of using the funds to pay for forest management activities (e.g., silviculture), for community facilities (e.g., health center), or of dividing (part) of the funds between members (cash distribution). In cases where the commons have already been formally or informally divided, it will not be possible to implement communal forest management. Where this is not the case, those who have no land or rights could benefit from community facilities and possibly from labor payments if they are considered eligible but are unlikely to benefit from any cash distribution; in any case, they will still lose access to the commons areas that they previously used (i.e. before REDD+ or PES implementation). Meanwhile the richest members of the community stand to lose most as they de facto currently gain a proportionally greater return from the resources. If the benefits (direct or indirect) that they receive do not match their opportunity costs, it is likely that they will oppose the scheme, and if it is imposed, they will almost certainly displace their activities elsewhere, leading to the potential risk of carbon leakage.

If the scheme alternatively aims to make payments to individuals for more sustainable management of their own plots, it is clear that those without land and rights will be totally excluded, not only from cash distribution but also from any income they used to gain as renters and share croppers as the owners turn these plots over to conservation. Those with larger holdings would be eligible for greater payouts, but it is unlikely they will accept them if they are below the opportunity costs of the current uses, and their opportunity costs are relatively high on a per hectare basis. As in the community payment scenario, the question of potential displacement of cattle and resulting leakage would have to be considered. Those who depend mainly on shifting cultivation, and are landowners, would probably do best under this scheme, as their profits (opportunity costs) per hectare are low [19].

We acknowledge, however, some limitations, as our results are not capable of generalizing conclusions on a larger scale given that drivers of change vary by geographic area. In addition, because of the limit of observations available in our sample, we were not able to include some important variables such as migration and the effects of subsidy programs paid by the government in the study area. Finally, farmers are not always propelled by strictly monetary incentives in their production decisions, and social preferences for traditional practices may also play a role in their decision making. Our results do not capture these effects of local traditions and social preferences.

\section{Conclusions}

In Mexico, REDD+ pilot schemes have been started in a number of areas, including the study area described here, and there is expectation that lessons will be learned and the program will be expanded later. In the past, the higher dependency of poor households on forests was seen as a cause of forest degradation. We show here that on balance it is in fact the richer farmers in the community who are responsible for the greater share of this degradation. Overall, raising beef cattle requires fencing poles, which are an important and often overlooked by-product of shifting cultivation; they are regularly purchased from smaller farmers by farmers in possession of large herds of cattle, as are low-cost maize crop residues, which are used for cattle fodder. These are very important factors directly associated with the amount of temporarily clearance of TDF, and as we have shown here, their production has important socio-economic features, showing a dependency between the richer and poorer groups in the community.

The practice of shifting cultivation reveals the dependence of the oldest and poorest farmers upon an inexpensive agriculture system for food security and the lack of opportunities for those without 
land rights (about $12 \%$ of our sample) who are unlikely to benefit from REDD+ unless funds are spent on community facilities or used to pay labor costs for activities related to REDD+.

In addition to the existence of socio-economic classes within communities, our study makes clear that the design of REDD+ programs needs to take into account (1) farmers' opportunity costs, which vary greatly between different classes of farmers; (2) the size of the incentives in comparison to these opportunity costs; (3) whether the payments are made communally or individually; and (4) the extent to which common land has already been individualized, formally or informally.

Supplementary Materials: The following are available online at http://www.mdpi.com/1999-4907/10/10/893/s1.

Author Contributions: Conceptualization, A.B. and M.S.; methodology, A.B.; software, A.B.; validation, A.B.; formal analysis, A.B.; investigation, A.B. and M.S.; writing-original draft preparation, A.B.; writing-review and editing, A.B. and M.S.

Funding: This research was funded by the ClimateWorks Foundation, under the project "Addressing forest degradation in Mexico through REDD+".

Acknowledgments: The authors acknowledge the financial support of the PAPIIT-UNAM IN300519 and the Catedra CONACyT -1539 project. We thank the farmers in the study site for their contributions to the study.

Conflicts of Interest: The authors declare no conflict of interest.

\section{References}

1. Chamberlain, J.L.; Cunningham, A.B.; Nasi, R. Diversity in Forest Management: Non-Timber Forest Products and Bush Meat. Renew. Resour. J. 2004, 22, 11-19.

2. Chomitz, K.M.; Kumari, K. The domestic benefits of tropical forests: A critical review. World Bank Res. Obs. 1998, 13, 13-35. [CrossRef] [PubMed]

3. Richards, J.F.; Tucker, R.P. World Deforestation in the Twentieth Century; Duke University Press: Durham, UK, 1988.

4. Sunderlin, W.D.; Angelsen, A.; Belcher, B.; Burgers, P.; Nasi, R.; Santoso, L.; Wunder, S. Livelihoods, forests, and conservation in developing countries: An Overview. World Dev. 2005, 33, 1383-1402. [CrossRef]

5. Baccini, A.; Goetz, S.J.; Walker, W.S.; Laporte, N.T.; Sun, M.; Sulla-Menashe, D.; Hackler, J.; Beck, P.S.A.; Dubayah, R.; Friedl, M.A.; et al. Estimated carbon dioxide emissions from tropical deforestation improved by carbon-density maps. Nat. Clim. Chang. 2012, 2, 182-185. [CrossRef]

6. Houghton, R.A.; Hackler, J.L. Sources and sinks of carbon from land-use change in China. Glob. Biogeochem. Cycles 2003, 17, 1034. [CrossRef]

7. Van Der Werf, G.R.; Morton, D.C.; DeFries, R.S.; Olivier, J.G.J.; Kasibhatla, P.S.; Jackson, R.B.; Collatz, G.J.; Randerson, J.T.; Kasibhatla, P. CO2 emissions from forest loss. Nat. Geosci. 2009, 2, 737-738. [CrossRef]

8. Skutsch, M.; Paneque-Gálvez, J.; Ghilardi, A.; Balderas Torres, A.; Morfin-Rios, J.; Michel-Fuentes, J.M.; Carrillo, O.; Ross, D. Adapting REDD+ Policy to Sink Conditions. For. Policy Econ. 2017, 80, 160-166. [CrossRef]

9. Baccini, A.; Walker, W.; Carvalho, L.; Farina, M.; Houghton, R.A. Response to Comment on “Tropical Forests Are a Net Carbon Source Based on Aboveground Measurements of Gain and Loss". Science 2017, 363, 230-234. [CrossRef]

10. Ahmad, A.; Liu, Q.-J.; Nizami, S.; Mannan, A.; Saeed, S. Carbon emission from deforestation, forest degradation and wood harvest in the temperate region of Hindukush Himalaya, Pakistan between 1994 and 2016. Land Use Policy 2018, 78, 781-790. [CrossRef]

11. Angelsen, A.; Kaimowitz, D. Rethinking the Causes of Deforestation. World Bank Res. Obs. 1999, 14, 73-98. [CrossRef]

12. Geoghegan, J.; Villar, S.C.; Klepeis, P.; Mendoza, P.M.; Ogneva-Himmelberger, Y.; Chowdhury, R.R.; Turner, B.; Vance, C. Modeling tropical deforestation in the southern Yucatán peninsular region: comparing survey and satellite data. Agric. Ecosyst. Environ. 2001, 85, 25-46. [CrossRef]

13. Geist, H.J.; Lambin, E.F. Proximate Causes and Underlying Driving Forces of Tropical Deforestation. BioScience 2002, 52, 143. [CrossRef]

14. Börner, J.; Wunder, S.; Brner, J. Paying for avoided deforestation in the Brazilian Amazon: from cost assessment to scheme design. Int. For. Rev. 2008, 10, 496-511. [CrossRef] 
15. Grieg-Gran, M. The Cost of Avoiding Deforestation Update of the Report Prepared for the Stern Review of the Economics of Climate Change. Available online: https://pubs.iied.org/G02489/ (accessed on 21 February 2019).

16. CIFOR. Site Selection for Forest Carbon Projects. In Analysing REDD+: Challenges and choices; Angelsen, A., Brockhaus, M., Sunderlin, W., Verchot, L., Eds.; CIFOR: Bogor, Indonesia, 2012; Volume 1, pp. $209-232$.

17. Rudel, T.K. Changing agents of deforestation: From state-initiated to enterprise driven processes, 1970-2000. Land Use Policy 2007, 24, 35-41. [CrossRef]

18. Santilli, M.; Moutinho, P.; Schwartzman, S.; Nepstad, D.; Curran, L.M.; Nobre, C. Tropical Deforestation and the Kyoto Protocol. Clim. Chang. 2005, 71, 267-276. [CrossRef]

19. Ickowitz, A.; Sills, E.; de Sassi, C. Estimating Smallholder Opportunity Costs of REDD+: A Pantropical Analysis from Households to Carbon and Back. World Dev. 2017, 95, 15-26. [CrossRef]

20. Van Khuc, Q.; Tran, B.Q.; Meyfroidt, P.; Paschke, M.W. Drivers of deforestation and forest degradation in Vietnam: An exploratory analysis at the national level. For. Policy Econ. 2018, 90, 128-141. [CrossRef]

21. Foley, J.A.; Asner, G.P.; Costa, M.H.; Coe, M.T.; DeFries, R.; Gibbs, H.K.; Howard, E.A.; Olson, S.; Patz, J.; Ramankutty, N.; et al. Amazonia revealed: forest degradation and loss of ecosystem goods and services in the Amazon Basin. Front. Ecol. Environ. 2007, 5, 25-32. [CrossRef]

22. Asner, G.P.; Knapp, D.E.; Broadbent, E.N.; Oliveira, P.J.C.; Keller, M.; Silva, J.N. Selective Logging in the Brazilian Amazon. Science 2005, 310, 480-482. [CrossRef]

23. DeFries, R.S.; Houghton, R.A.; Hansen, M.C.; Field, C.B.; Skole, D.; Townshend, J. Carbon emissions from tropical deforestation and regrowth based on satellite observations for the 1980s and 1990s. Proc. Natl. Acad. Sci. USA 2002, 99, 14256-14261. [CrossRef]

24. Müller, D.; Sun, Z.; Vongvisouk, T.; Pflugmacher, D.; Xu, J.; Mertz, O. Regime shifts limit the predictability of land-system change. Glob. Environ. Chang. 2014, 28, 75-83. [CrossRef]

25. Kissinger, G.; Herold, M.; Sy, V.D. Drivers of Deforestation and Forest Degradation: A Synthesis Report fo REDD+ Policymakers.; Lexeme Consulting: Vancouver, BC, Canada, 2012.

26. Shearman, P.L.; Ash, J.; Mackey, B.; Bryan, J.E.; Lokes, B. Forest Conversion and Degradation in Papua New Guinea 1972-2002. Biotropica 2009, 41, 379-390. [CrossRef]

27. Damnyag, L.; Saastamoinen, O.; Blay, D.; Dwomoh, F.K.; Anglaaere, L.C.; Pappinen, A. Sustaining protected areas: Identifying and controlling deforestation and forest degradation drivers in the Ankasa Conservation Area, Ghana. Boil. Conserv. 2013, 165, 86-94. [CrossRef]

28. Medrilzam, M.; Dargusch, P.; Herbohn, J.; Smith, C. The Socio-Ecological Drivers of Forest Degradation in Part of the Tropical Peatlands of Central Kalimantan, Indonesia. Forestry 2014, 87, 335-345. [CrossRef]

29. Houghton, R.A.; House, J.I.; Pongratz, J.; Van Der Werf, G.R.; DeFries, R.S.; Hansen, M.C.; Le Quéré, C.; Ramankutty, N. Carbon emissions from land use and land-cover change. Biogeosciences 2012, 9, 5125-5142. [CrossRef]

30. Hosonuma, N.; Herold, M.; De Sy, V.; De Fries, R.S.; Brockhaus, M.; Verchot, L.; Angelsen, A.; Romijn, E. An assessment of deforestation and forest degradation drivers in developing countries. Environ. Res. Lett. 2012, 7, 044009. [CrossRef]

31. Angelsen, A.; Jagger, P.; Babigumira, R.; Belcher, B.; Hogarth, N.J.; Bauch, S.; Börner, J.; Smith-Hall, C.; Wunder, S. Environmental Income and Rural Livelihoods: A Global-Comparative Analysis. World Dev. 2014, 64, S12-S28. [CrossRef]

32. Borrego, A.; Skutsch, M. Estimating the opportunity costs of activities that cause degradation in tropical dry forest: Implications for REDD+. Ecol. Econ. 2014, 101, 1-9. [CrossRef]

33. Morales-Barquero, L.; Borrego, A.; Skutsch, M.; Kleinn, C.; Healey, J.R. Identification and quantification of drivers of forest degradation in tropical dry forests: A case study in Western Mexico. Land Use Policy 2015, 49, 296-309. [CrossRef]

34. Cavendish, W. Empirical Regularities in the Poverty-Environment Relationship of Rural Households: Evidence from Zimbabwe. World Dev. 2000, 28, 1979-2003. [CrossRef]

35. Sills, E.O.; Sharachchandra, L.; Holmes, T.P.; Pattanayak, S.K. Nontimberforest Products in the Rural Household Economy. In Forest in a Market Economy; Sills, E.O., Lee Abt, K., Eds.; Kluwer Academic Publishers: Dordrecht, The Netherlands, 2003.

36. DiGiano, M.; Ellis, E.; Keys, E. Changing Landscapes for Forest Commons: Linking Land Tenure with Forest Cover Change Following Mexico's 1992 Agrarian Counter-Reforms. Hum. Ecol. 2013, 41, 707-723. [CrossRef] 
37. Merino, L. Las Políticas Forestales y de Conservación y Sus Impactos Sobre Las Comunidades Forestales. Estud. Agrar. 2001, 18, 75-115.

38. De Ita, A. Land Concentration in Mexico after PROCEDE. In Promised Land. Competing Visions of Agrarian Reform; Rosset, P., Courville, M., Eds.; Food Firs Books: New York, NY, USA, 2006.

39. Dunn, M.H. Privatization, Land Reform, and Property Rights: The Mexican Experience. Const. Polit. Econ. 2000, 11, 215-230. [CrossRef]

40. De Janvry, A.; Gonzalez-Navarro, M.; Sadoulet, E. Are land reforms granting complete property rights politically risky? Electoral outcomes of Mexico's certification program. J. Dev. Econ. 2014, 110, 216-225. [CrossRef]

41. Kowler, L.F.; Ravikumar, A.; Larson, A.M.; Rodriguez-Ward, D.; Burga, C.; Tovar, J.G. Analyzing Multilevel Governance in Peru; CIFOR: Bogor, Indonesia, 2016.

42. Kaimowitz, D.; Angelsen, A. Economic Models of Tropical Deforestation a Review; CIFOR: Bogor, Indonesia, 1998.

43. Barsimantov, J.; Kendall, J. Community Forestry, Common Property, and Deforestation in Eight Mexican States. J. Environ. Dev. 2012, 21, 414-437. [CrossRef]

44. Ludeke, A.K.; Maggio, R.C.; Reid, L.M. An analysis of anthropogenic deforestation using logistic regression and GIS. J. Environ. Manag. 1990, 31, 247-259. [CrossRef]

45. Mertens, B.; Lambin, E.F. Land-Cover-Change Trajectories in Southern Cameroon. Ann. Assoc. Am. Geogr. 2000, 90, 467-494. [CrossRef]

46. Etter, A.; McAlpine, C.; Wilson, K.; Phinn, S.; Possingham, H. Regional patterns of agricultural land use and deforestation in Colombia. Agric. Ecosyst. Environ. 2006, 114, 369-386. [CrossRef]

47. Informe Final. Análisis de Cambio de Cobertura y Uso Del Suelo, Escenario de Referencia de Carbono y Diseño Preliminar Del Mecanismo de Monitoreo. Available online: http://redd.ciga.unam.mx/files/ InformeFinal_JIRA_May10_12.pdf/ (accessed on 7 November 2018).

48. Salinas-Melgoza, M.; Skutsch, M.; Lovett, J.; Borrego, A. Carbon emissions from dryland shifting cultivation: a case study of Mexican tropical dry forest. Silva Fenn. 2017, 51, 51.1B. [CrossRef]

49. Hellin, J.; Erenstein, O.; Beuchelt, T.; Camacho, C.; Flores, D. Maize stover use and sustainable crop production in mixed crop-livestock systems in Mexico. Field Crop. Res. 2013, 153, 12-21. [CrossRef]

50. Vesk, P.A.; Westoby, M. Predicting Plant Species' Responses to Grazing. J. Appl. Ecol. 2001, 38, 897-909. [CrossRef]

51. Watkinson, A.R.; Ormerod, S.J. Grasslands, Grazing and Biodiversity: Editors' Introduction. J. Appl. Ecol. 2001, 38, 233-237.

52. Barbier, E.B.; Burgess, J.C. Economic analysis of deforestation in Mexico. Environ. Dev. Econ. 1996, 1, $203-239$. [CrossRef]

53. Salinas-Melgoza, M.A.; Skutsch, M.; Lovett, J.C. Predicting aboveground forest biomass with topographic variables in human-impacted tropical dry forest landscapes. Ecosphere 2018, 9, e02063. [CrossRef]

54. Dove, M.R. Theories of swidden agriculture, and the political economy of ignorance. Agrofor. Syst. 1983, 1, 85-99. [CrossRef]

55. Hecht, S. Valuing Land Uses in Amazonia: Colonist Agriculture, Cattle and Petty Extraction in Comparative Perspective. In Conservation of Neotropical Forests; Redford, K.H., Padoch, C., Eds.; Columbia University Press: New York, NY, USA, 1992; pp. 379-399.

56. Mertz, O.; Bruun, T.B. Shifting Cultivation Policies in Southeast Asia: A Need to Work with, Rather than Against, Smallholder Farmers. In Shifting Cultivation Policies: Balancing Environmental and Social Sustainability; CABI Publishing: Egham, UK, 2017; pp. 27-42.

(C) 2019 by the authors. Licensee MDPI, Basel, Switzerland. This article is an open access article distributed under the terms and conditions of the Creative Commons Attribution (CC BY) license (http://creativecommons.org/licenses/by/4.0/). 